three times daily at each station at the same hours as at the base, whence results were sent by wireless after each reading to Norway.

The net balance of the ice cap-that is to say, the ratio between the factors of accumulation and ablation-was determined for the west ice over the year, and preliminary discussion of the results obtained indicate that the northern part of the ice cap is probably both shrinking and retreating. The different factors obtaining both in accumulation and ablation were separately measured and their relative proportions assessed, while research was also made on various physical questions connected with the ice itself and with the change of snow into ice. The temperature gradient was measured down to a considerable depth, and it was found at the central station that the tem. perature remained at a fairly constant $0.0^{\circ} \mathrm{C}$. at a depth of $70 \mathrm{ft}$. Certain indications of the thickness of the ice were obtained indicating that at least the west ice is very much thinner than had been thought. A crevasse was discovered while digging a shaft at the central station, and through it we were able to penetrate to a depth of more than $70 \mathrm{ft}$., where an unfrozen ice lake was found (Fig. 3). The walls of the crevasse were covered with a glittering array of ice crystals while magnificent icicles across the passages formed curtains which had to be cut down before a way could be found along them (see also Nature, Nov. 7, p. 803).

At the base in Brandy Bay, Whatman and Hamilton were stationed practically continuously throughout the whole expedition. They were in charge of the important research on the ionosphere which was being carried out for the first time north of the auroral belt. Before departure from England, it had been feared that the severe climatic conditions would make it impossible successfully to accomplish this work, but so efficient was the whole apparatus and the Petter electrical generating unit, that not a single serious breakdown occurred over the entire year. The results are now being examined by investigators at the Radio Research Station at Slough, in co-operation with which, and also with the Norwegian Government Station at Tromsö, the records were taken. Special studies were also made of the aurora, and measurements were made of the atmospheric ozone.

By the end of August the scientific programme had been accomplished and the M.S. Heimland arrived in Brandy Bay on August 21. The base hut has been bought by the Norwegian Government, and after it had been inspected and the stores and equipment loaded on to the ship, we left Brandy Bay on the following evening.

\title{
Scientific Centenaries in 1937
}

\author{
By Eng.-Capt. Edgar C. Smith, O.B.E., R.N.
}

$\mathrm{W}^{\mathrm{n}}$ HEN reference was made in these columns a year ago to the scientific centenaries in 1936, the first man of science to be recalled to mind was the famous German mathematician Johann Müller, or Regiomontanus, who was born in 1436. In reviewing the centenaries which will fall this year the first name to be included is that of Christopher Clavius (1537-1612) whose birth occurred a century later. Born at Bamberg, in Germany, he entered the Society of Jesus, taught for many years in Rome - earning for himself the appellation of "the Euclid of the 16th Century"was employed by Pope Gregory XIII on the reformation of the calendar, and in 1604 published his most important book, "Geometria Practica". He died February 6, 1612. Another mathematical worthy of the sixteenth and seventeenth centuries was Henry Gellibrand, who was born in London in 1597 and died as Gresham professor of astronomy in February 1636 (o.s.) or 1637 (N.S.).
It was Sir Henry Savile who turned Gellibrand's attention to mathematics, and at the Gresham College he became the close friend of Henry Briggs.

"Mr. Gellibrand's situation at the College, free Converse with the Lovers of Mathematical Studies, and diligent Enquiries, gave him," wrote Benjamin Martin, "an Opportunity of contributing much to the Improvement of Navigation, which probably would have owed more to him had he lived longer: But he was taken off February 9,1636 , in the 40th Year of his Life, and was buried in the Church of St. Peter the Poor, without any Inscription to his Memory".

The year 1637 also saw the birth of another English mathematician who had but a short life, William Neile, who died at the age of thirty-four years. He had been elected a member of the Council of the Royal Society at the age of thirty, and according to the antiquary Hearne, his 
powerful genius for mathematical studies was such "that had he not been cut off in the prime of his years in all probability he would have equalled, if not excelled, the celebrated men of that profession".

Whatever interest is to be found in the lives of Clavius, Gellibrand and Neile, however, is far surpassed by that which surrounds the activities and strange ending of the great Dutch naturalist Jan Swammerdam (1637-80). He imbibed a love of natural history from his father, and was trained for medicine. He became famous both as an anatomist and as a microscopist.

"Swammerdam," said Prof. Miall, "treated the microscope as an instrument of continuous biological research. In his eyes it was a sacred duty to explore with the utmost faithfulness the minute works of the Creator. Insects yielded him an inexhaustible supply of natural contrivances, in which closer scrutiny always brought to view still more exquisite adaptations to the conditions of life. He was able to throw a beam of steady light upon the perplexed questions of insecttransformation, and swept from his path the sophistries with which the philosophy of the schools had obscured the change of the caterpillar into a moth, or of the tadpole into a frog. . . . $\mathrm{He}$ bequeathed to his successors many noble examples of the way in which life-histories ought to be investigated."

About 1672, Swammerdam came under the influence of that strange religious visionary, Antoinette Bourignon, and, already of feeble constitution, he slowly sank into an early grave through overwork and the melancholy engendered by mysticism. Under the pressure of indigence he had sold many of his writings and drawings. These came into the possession half a century later of Boerhaave, who caused them to be published under the title "Biblia Naturæ", in 1737.

Passing from the men of science who laboured in the seventeenth century to those who belong to the eighteenth century, the outstanding name is that of Aloisio Galvani, the bicentenary of whose birth falls on September 9. Born at Bologna, he was educated, and practised and lectured there, and it was there he made his discoveries on animal electricity which his countryman Volta referred to as "a great and luminous discovery which forms an epoch in the annals of physical and medical science". His death took place in 1798; the centenary of which event was marked by suitable ceremony at Bologna. Of other men born in 1737, mention may be made of Dr. Richard Watson (1737-1816), Bishop of Llandaff, who lectured at Cambridge on chemistry; Guyton de Morveau (1737-1816), whose career is noticed in another column (p. 18); Jean-Nicolas Ceré (1737-1810), who as director of the Royal Botanical Garden at Mauritius earned the gratitude of European naturalists by his gifts of plants; Alexander Dalrymple (1737-1808) who, in his early days a writer in the East India Company's service, rose to be hydrographer to both the East India Company and the Admiralty; William Bayly (1737-1810), the astronomer who accompanied Cook on some of his voyages; William Forsyth (1737-1804), the Scottish horticulturist, whose name is recalled by one of our most beautiful of early flowering shrubs; Colonel H. Watson (1737-86), who translated Euler's work on the construction and manœuvring of ships and practised naval architecture with great success; and Dr. Charles Hutton (1737-1823). Hutton began life with few advantages, but by unremitting labour gained for himself a prominent place among British mathematicians. For thirty years he was a professor at the Royal Military Academy, Woolwich, and in 1779 he became the foreign secretary to the Ruyal Society. He was editor of the Ladies' Diary, made the calculations in connexion with Maskelyne's experiments on the density of the earth, carried out experiments on gunnery, and in 1795 published a valuable mathematical and philosophical dictionary.

Of those whose lives began in the eighteenth century but who died a hundred years ago, the one with, perhaps, the highest reputation was Karl Ernst Adolf von Hoff (1771-1837), the German geologist to whom a tribute was paid in NATURE for June 8, 1905 . "Von Hoff's position as an original thinker," it has been said, "is at least equal to that of Lyell." A diplomatist and immersed in the international confusion of the Napoleonic era, he yet found time to establish a geological journal in 1801 and carried on those studies which led to the writing of his great work, "The History of the Changes in the Surface of the Earth". Other men of science who died in $\mathbf{1 8 3 7}$ include Edward Turner (1798-1837), professor of chemistry in University College, London, who did important work on the atomic weights of the elements ; William Ritchie (1790-1837), a student under Gay Lussac and Biot, who in 1829 became professor of natural philosophy at the Royal Institution; Domenico Scina (1765-1837), a learned Sicilian physicist who became chancellor of the University of Palermo ; Martin van Marum (1750-1837), a Dutch physicist who made many electrical experiments and was secretary to the scientific society of Haarlem; and John Latham (1740-1837), the ornithologist, who at eighty years of age began his "General History of Birds" (1821-28). To engineers the name of Arthur Woolf (1766-1837) recalls many important improvements in the steam engine, while that of Claude-Pierre 
Molard (1758-1837) will always be associated with the foundation in Paris of the Conservatoire des Arts et Métiers. Early in his career, Molard was brought into contact with Vaucanson, and was placed in charge of the collection of models which Vaucanson gave to France. It was only natural that when the Government, on the report of the Abbé Grégoire, decided to found the Conservatoire, Molard should be appointed its first director. When elected to the Paris Academy of Sciences, Molard was given the seat vacated by Napoleon.

During the last hundred years, through various causes science has engrossed the attention of so many workers that the list of men eminent for one reason or another who were born in 1837, a century ago, is a long one. The list given below does not claim to be complete, but the notes given will suffice to recall some of the activities of the nineteenth century. Among the ranks of the physicists, Eleuthere Elie Nicolas Mascart (18371908) was certainly one of the most widely known scientific men of his day. As successor to Regnault at the Collège de France, as director of the Central Bureau of Meteorology in Paris, and as president of the Paris Academy of Sciences, he rendered notable service to science in France, while as president of various international gatherings he had a wide reputation as an organizer. He died on August 26, 1908, and was buried with military honours in the cemetery of Montparnasse, in which rest the remains of Regnault, Biot, Foucault, Dumas and Ampère. Another eminent French physicist born in 1837 was Emile Sarrau (18371904), a professor in the Ecole Polytechnique and for many years director of the laboratory of the Ecole des Poudres et Salpêtres. He wrote on light, heat, gases and ballistics, and was a collaborator with Berthelot on investigations on explosives. The year 1837 also saw the birth of the German meteorologist Wilhelm von Bezold (1837-1907), director of the Meteorological Institute in Berlin; of Admiral Carl Koldeway (1837-1908), the commander of two arctic expeditions and an authority on magnetism ; of Johann Diderik van der Waals (1837-1923), the eminent Dutch physicist; and of the Belgian Jesuit Eugène Lafont (1837-1908), a pioneer in scientific education in India. Sent to St. Xavier's College, Calcutta, in 1865, Lafont erected a meteorological and astronomical observatory and a physical laboratory, and afterwards took an active part in the work of the University of Calcutta, and was a founder of the Indian Association for the Cultivation of Science.

What Lafont did for physics in India, Edward Divers (1837-1912) did for chemistry in Japan. In 1873, at the invitation of the Public Works Department of that country, he with ten other
Englishmen went to Tokyo to found a college of engineering. For twenty-six years he laboured there, and to-day a bronze statue of him stands in one of the courtyards of the Imperial University. In 1905-6 he was president of the Society of Chemical Industry. The chemist, John Alexander Reina Newlands (1837-98), was also born a hundred years ago. As a young man of twentythree years of age he fought under Garibaldi for Italian freedom, and it was soon after his return home and while practising as an analytical chemist in London, that he sent a letter to the Chemical News containing his earliest views on periodicity among the chemical elements; views which were regarded at first as fantastic but which afterwards gained for him the Davy Medal of the Royal Society.

The ranks of astronomers have ever been recruited from many sources, some of the most eminent workers in this science beginning their careers in circumstances which were little likely to lead them to the computing room and the observatory. This is exemplified by the lives of several men whose centenaries fall this year. Richard Antony Proctor (1837-88), one of the most popular lecturers and writers on astronomy, and one of the keenest observers, began life as a bank clerk in London; Ralph Copeland (18371905), who was Astronomer Royal for Scotland in 1889-1905, spent his early years on the sheepruns and amid the gold diggings of Australia, while Frank McClean (1837-1904), as well known for his generous gifts to astronomy as for his own work on the spectra of the stars, was originally a civil engineer. William Harkness (1837-1903), too, who was born at Ecclefechan, Scotland, and who became director of the Naval Observatory at Washington, was a medical man before he became an astronomer, while his American contemporary Henry Draper (1837-82), in whose honour the United States Government struck a transit of Venus medal, was a professor of physiology. On the other hand, Edmund Weiss (1837-1917), assistant and successor of Littrow at the Vienna Observatory, began life as an astronomer. Another name of interest in connexion with these centenaries of astronomers is that of the American financier Charles Tyson Yerkes (1837-1905), who, with funds accumulated through his railway enterprises in Chicago, founded the Yerkes $\mathrm{Ob}$ servatory of the University of Chicago.

In conclusion, passing reference may be made to a few men distinguished for their work in various other branches of science or industry whose centenaries fall this year. Henry Hicks (1837-99), the president of the Geological Society in 1896-98, was a surgeon by profession, and it was his contact with J. W. Salter which 
made him a devoted student of geology and palæontology ; Raphael Pumpelly (1837-1923) turned geologist on coming under the influence of Noeggerath at Freiburg, and so embraced a profession which brought him a life full of adventure in many lands, while Thomas Davies (1837-93), who edited the Mineralogical Magazine, followed in the footsteps of his father William Davies (1814-91) when in 1858 he entered the service of the British Museum. Among metallurgists, few in his day were known better than George James Snelus (1837-1906), who for his work on the elimination of phosphorus from molten pig iron, received in 1883 one Bessemer Gold Medal, while another was given to Sidney Thomas. In Germany, no man did more to establish the engineering industry on a sound basis than Ludwig Loewe (1837-86), the founder of a still famous firm, while American invention and engineering are recalled by the names of Robert McAlpine (1837-1911), a pioneer in the manufacture of paper from ground wood pulp, and Colonel Washington Augustus Roebling (1837-1926), to whom fell the task of constructing the Brooklyn Bridge at New York.

\section{The Iguanodons in the Brussels Museum}

$\mathrm{W}^{\mathrm{B}}$ are glad to record that the unique collection of skeletons of the Wealden dinosaur Iguanodon in the Royal Museum of Natural History at Brussels has now been installed for safe preservation in two air-tight glass cases, which are probably the largest exhibition cases hitherto placed in a museum. The twelve skeletons, which are mounted in their natural position on iron framework, occupy a case which measures 18 metres in length, 11 metres in maximum width, and 7 metres in height. Part of it is shown in the accompanying photograph (Fig. 1). The skeletons which still lie attached to masses of rock are covered with a case measuring 20.5 metres in length, 13 metres in width, and 7 metres in height. The cases were made by the Belgian branch of the English firm, Messrs. Fred. Sage and Co. Ltd., which has supplied cases to the British Museum and to other English museums.

When these fossil bones were first extracted from the rock and prepared for study between 1878 and 1900, they were hardened with an aqueous solution of gelatine. The treatment, however, proved to be insufficient to prevent the decay of the iron pyrites with which most of the specimens were permeated, and a few years ago it became evident that the collection could only be preserved by some other method of hardening the bones and by protecting them in future from contact with more or less damp air.
To devise a new treatment was difficult, because much of the gelatine still remained in the fossils and prevented the absorption of any other material. Experiments were therefore made, and it was decided to remove the gelatine so far as possible

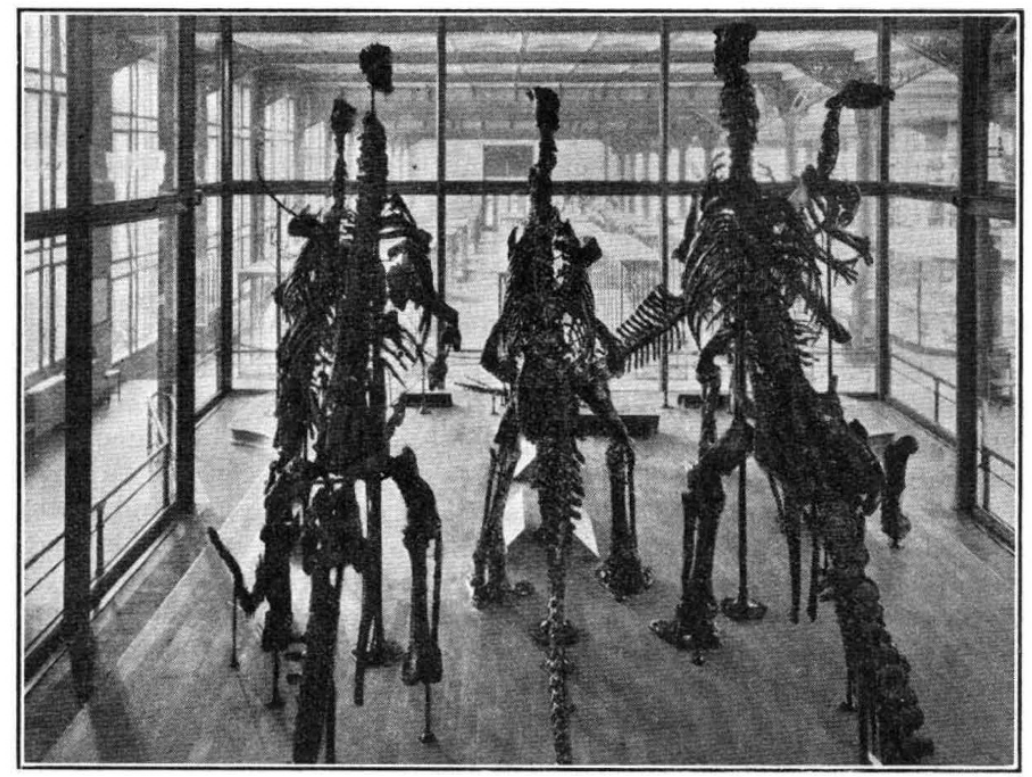

Fig. 1.

Iguanodons in the Royal Museum of Natural History, Britssels. Photo by E. Sergysels, Brux.

and replace it with shellac to be deposited from a solution in alcohol. The bones were washed with tepid soapy water to which a little carbonate of soda had been added, and after each washing they were rinsed with tepid water and carefully dried in a heated chamber. Immediately after drying, and while still at a temperature of $45^{\circ} \mathrm{C}$., they were placed for twenty-four hours or more, 